\title{
Reflections on Globalisation and Labour Standards in the Indian Garment Industry: Codes of Conduct Versus 'Codes of Practice' Imposed by the Firm
}

\author{
Alessandra Mezzadri, School of Oriental and African Studies
}

\begin{abstract}
The 'globalisation' of the garment industry has taken place in a context of increasing flexibilisation and informalisation of labour. Concerns of corporate social responsibility, especially in the form of codes of conduct, have been presented as a potential way to address this 'race to the bottom' for labour. Focusing on the experience of two important garment producing areas in India, Delhi and Bangalore, this paper shows that these codes have limited impact on improving working standards. This is due to a sharp mismatch between codes of conduct and the effective 'codes of practice' imposed by firms to deploy labour and organise the labour process. Firstly, codes are mainly elaborated as factorybased regulations, and are inapplicable to non-factory realms of production. However, these are remarkably significant in India. In Delhi, armies of urban and rural homeworkers are employed in highly complex production networks. Secondly, even in the factory-based realm of production, codes are only designed to target a workforce enjoying permanent status. However, in the Indian garment sector, the very meaning of 'permanent work' is currently being challenged by exporters in new innovative ways. In Bangalore, exporters engage in different processes of feminisation and re-feminisation of the factory workforce in order to minimise their responsibility towards labour. The analysis shows how local architectures of production crucially mediate the impact of given formal regulatory measures. Moreover, it also highlights how the firm can effectively be used as a fundamental prism through which to study labour and labour standards.
\end{abstract}

\section{KEY WORDS}

garment industry, India, informalisation, labour standards

\section{Introduction}

This paper discusses the limitations of Corporate Social Responsibility (CSR) approaches to labour standards drawing on evidence from the Indian export-oriented garment industry. The garment industry is one of the most 'globalised' industries in the world. Production is scattered across an increasing number of countries, particularly in Asia and 
Latin America. Its progressive globalisation and transnationalisation have taken place in a context of increasing casualisation and informalisation of labour; a real 'race to the bottom' for workers in developing regions. Informalisation patterns have involved both the spread of informal employment relations as well as the increasing use of informal mechanisms of labour control that exploit deeply-rooted local structures of power. Patriarchy has been one of the leading tools used to discipline and control the garment labour force in East Asia and Latin America, paving the way to the feminisation of labour in the industry. In India there are today multiple and complex ways in which the process of informalisation of labour manifests itself, exploiting caste, gender, age, mobility and geographical provenance. Overall, the garment industry seems systematically unable to deliver 'decent work' to its labourers. Increasing awareness over the vulnerable and precarious conditions of the garment workforce in developing regions has led to increasing anti-sweatshops campaigning and to the rise, in the 1990s, of CSR initiatives. In the context of these initiatives, global buyers have elaborated voluntary codes of conduct that are meant to set given global labour standards. This paper first makes some general reflections on the theoretical flaws of the CSR agenda and its inability to speak for the working poor. It then moves on to illustrate the lack of effectiveness of the CSR agenda on the ground through the experiences of two Indian garment centres: Delhi and Bangalore. In Delhi, the limited effectiveness of codes of conduct is linked to their elaboration as factory regulations targeting a permanent labourforce, in a context where, on the contrary, labour relations are temporary and where a considerable part of the product cycle takes place outside the factories. However, also in Bangalore, where product cycles are more stable and standardised and where the workforce is effectively permanent, codes of conduct have limited applicability. In fact, even in a context apparently dominated by permanent labour relations, exporters engage in strategies and tactics to circumvent labour laws and to challenge and re-craft the very meaning of permanent work to their own advantage. The factory workforce, mainly composed by female workers, is today going through new patterns of feminisation and greater vulnerability.

In both these two cases, attempts to impose given codes of conduct clash with the 'codes of practice' imposed by firms and local actors on the ground. These codes of practice, that mediate different and complex processes of informalisation of labour, cannot but escape attempts at standardising working conditions. Where CSR norms are aimed at the creation of a universal system of knowledge (Blowfield 2005), firms actively use very locally embedded and diverse forms of knowledge to their advantage. Arguably, it is through firms' practices that real labour standards are created on the ground, and these differ substantially from the idealised benchmarks set by global business. This point may have useful methodological implications for future studies on labour standards. These studies should take into much greater consideration the relevance of local architectures of production as they are shaped by local actors and firms. This paper is based on quantitative and qualitative findings gathered during two rounds of fieldwork in India, between October 2004 and July 2005, and between March and April 2010. ${ }^{1}$ 


\section{The Garment Industry: Globalising Production, Informalising Labour}

The garment industry is well known to be a 'global' industry. Organised in what Gereffi and Korzeniewicz (1994) defined as 'buyer-driven global commodity chains', this industry went through different processes of location and relocation of production, acquiring a prominent place in the development strategies of several developing regions. By the 1970s, garment production had largely relocated to East Asia, where it became one of the leading export sectors. In the following decades, the rapid growth of what the World Bank called the East Asian 'miracle economies', together with the establishment of a quota system for exporting countries - the Multi Fibre Agreement (MFA) - triggered further processes of relocation of the industry. Soon, production reached Southeast Asia, Latin America, China, and finally South Asia (see Gereffi and Ramaswamy, 2000).

This progressive 'globalisation' of production went hand in hand with the establishment and perpetuation of very flexible, casualised and informalised employment relations. It can be argued that the garment industry has always been characterised by casualised and precarious working arrangements. As early as 1901, the economist John R. Commons (quoted in Howard, 1997: 152) used the expression 'sweatshop system' with reference to clothing production. This was defined as a system of subcontract, wherein the work is led out to contractors to be done in small shops or homes', to be contrasted with the factorysystem, 'wherein the manufacturer employs his own workmen...in his own building' (ibid).

Since its first move to the developing world in the 1950s and 1960s, the now 'global' garment industry reproduced and strengthened these specific employment features. Numerous studies of the industry in East Asia stress the highly casualised and precarious nature of jobs provided and promoted by the industry (see, for instance, Bonachich et al 1994, Bonachich and Appelbaum 2000, Rosen 2002, Chang, 2009). Indeed, the industry was among the first in exploiting local gender differences and patriarchal structures to provide the global economy with an easily controllable labour force, mainstreamed as 'docile' and highly productive (Rosen 2002). This process of 'feminisation' of labour (Standing 1999) responded to the need to reproduce labour as a cheap, disposable commodity. Feminisation has meant both a rise in women workforce participation rates and an expansion of insecure and precarious jobs, traditionally geared to women (Standing 1999, Salzinger, 2003).

Although indeed gender is a crucial axis of differentiation to segment the labour force, it is not the only social structure that can be deployed for this task. As the globalisation of garment production progresses, evidence from different exporting regions highlight the multiple types of strategies and tactics through which labour flexibility is achieved and reproduced. In China, the leading world player in garment export since the expiry of the MFA in 2005, evidence from the export-hubs situated in the Guangdong region show the increasing role of mobility, rural-urban differentials and structural inequalities in producing a vast pool of flexible and 'disposable' workers (see Pun 2006, and Chan 2002).

This process whereby casualisation is increasingly obtained via the exploitation of different pre-existing structural differences and inequalities is considered here as one of the leading features of the process of informalisation of labour. It must be noted that informalisation, in this sense, refers to both the increasing dominance of informal labour 
in given industrial regimes as well as to the increasing regulation of such labour through given social mechanisms which generally pertain to the informal economy. The globalisation of garment production has gone hand in hand with this process of informalisation. In India, this dual development of the industry is mirrored in aggregate data as well as in qualitative accounts of garment production and labour trends in different industrial areas.

\section{The Indian Garment Industry and Its Rising Informalisation}

In India, garment export started rising considerably by the early 1980s (see Table 1). By 2005 India was exporting US\$9.2 billion in apparel (Tewari 2008). By 2007, exports reached 9.45 billion, and India ranked $7^{\text {th }}$ among the top 15 apparel exporters, with a share of world export set at 4.00percent (UNIDO 2009). In India, garment production is concentrated in a number of key industrial areas. The Apparel Export Promotion Council (AEPC), the government institution in charge of quota allocation under the MFA, identified these areas as Delhi, Ludhiana, Jaipur, Calcutta, Mumbai, Chennai, Bangalore and Tiruppur. According to AEPC, there are also two Export Processing Zones (EPZs) in Hyderabad and Cochin, although export turnover from these industrial areas still appears to be negligible (AEPC 2004).

Table 1. Share of readymade garments in India's exports 1960-1961 to 2000-2001

\begin{tabular}{|l|c|c|c|}
\hline $\begin{array}{c}\text { Year } \\
\text { Value/ } \\
\text { Percentage }\end{array}$ & $\begin{array}{c}\text { Readymade garment } \\
\text { export } \\
\text { (Rs. Million) }\end{array}$ & $\begin{array}{c}\text { Total export } \\
\text { (Rs. } \\
\text { Million) }\end{array}$ & $\begin{array}{c}\text { Percentage of readymade } \\
\text { out of total export }\end{array}$ \\
\hline $1960-61$ & 10 & 6430 & 0.16 \\
\hline $1970-71$ & 290 & 15,350 & 1.89 \\
\hline $1980-81$ & 5,500 & 67,110 & 8.20 \\
\hline $1990-91$ & 40,120 & 886,690 & 12.32 \\
\hline $1994-95$ & 103,050 & 886,690 & 11.6 \\
\hline $2000-01$ & 254,780 & $2,035,710$ & 12.52 \\
\hline
\end{tabular}

Source: Author's adaptation from Table 3.1 in Singh and Kaur Sapra (2007: 43); based on DGCI\&S data cited in Economic Survey 2002-2003, Table 7.3, 7.4, Government of India, various issues.

As Indian garment centres are increasingly incorporated into global networks, a rising number of workers tie their livelihoods to the fortunes of this sector. According to the Ambekar Institute of Labour Studies (1980), by the late 1970s, the larger share of labour in garment export was located between Delhi, Tamil Nadu and Maharashtra. There were some 45,000 garment workers in Delhi, 32,000 in Tamil Nadu, 112,000 in Maharashtra (Ambekar Institute of Labour Studies 1980). Today, these estimates have 
risen exponentially. According to informal estimates provided by various AEPC local branches, by the Clothing Manufacturer Association of India (CMAI) and by the Tiruppur Exporters Association (TEA), the export-oriented garment industry employs approximately 1,826,000 in Delhi, Jaipur, Mumbai, Chennai, Bangalore and Tiruppur alone (Table 2). These estimates generally refer to factory-labour, and thus omit the vast number of non-factory based workers. ${ }^{2}$

Table 2. Factory-based employment estimates in selected garment export clusters

\begin{tabular}{|l|c|}
\hline Indian garment cluster & Employment estimate (factory sector) \\
\hline Delhi & 336,000 \\
\hline Jaipur & 50,000 \\
\hline Mumbai & 140,000 \\
\hline Chennai & 700,000 \\
\hline Bangalore & 300,000 \\
\hline Tiruppur & 300,000 \\
\hline Total & $1,826,000$ \\
\hline
\end{tabular}

Source: fieldwork finding, based on interviews with AEPC-Delhi, AEPC-Jaipur, AEPC-Chennai, CMAIBangalore and TEA held between October 2004 and July 2005.

According to Rani and Unni (2004), patterns of employment generation in the garment export industry in India have gone through two different phases. In the first phase, until the mid 1990s, employment was mainly generated by the formal sector. In the second phase instead, from the mid 1990s onwards, the industry mainly generated informal employment. The same trend applies to the generation of value-added in the industry. Mainly led by the formal sector until the mid 1990s, increases in value-added from the mid 1990s onwards started being primarily provided by the informal sector. ${ }^{3}$

Table 3. Growth rates employment and value-added in Indian organised \& unorganised wearing apparel

\begin{tabular}{|l|c|c|c|c|}
\hline \multirow{2}{*}{ Wearing } & \multicolumn{2}{|c|}{ Value added } & \multicolumn{2}{c|}{ Employment } \\
\cline { 2 - 5 } & $\begin{array}{c}1989-90 \text { to } \\
1994-5\end{array}$ & $\begin{array}{c}1994-5 \text { to } \\
1999-2000\end{array}$ & $\begin{array}{c}1989-90 \text { to } \\
1994-95\end{array}$ & $\begin{array}{c}1994-5 \text { to } \\
1999-2000\end{array}$ \\
\hline Organised & 27.0 & 2.3 & 17.3 & 3.8 \\
\hline Unorganised & 6.2 & 14.9 & 0.7 & 15.2 \\
\hline
\end{tabular}

Source: adapted from Rani and Unni (2004: 4577, Table 7; data from NSSO 1989-2002, CSO 19852002). 
These figures show that the Indian garment sector is effectively going through a steady process of informalisation. Fieldwork findings show that informalisation manifests itself with different local modalities in the eight main export hubs (Mezzadri 2009). In each area, exporters exploit to their advantage the many social structures and structural differences already paving the way to accumulation patterns in the Indian informal economy (see Harriss-White, 2003).

In northern export areas, industrial systems are particularly fragmented and layered, and informalisation patterns involve the exploitation of gender, caste, age, and geographical provenance. In southern areas, particularly in Bangalore and Chennai, where industrial systems are less fragmented, the local modalities of informalisation are crafted around the feminisation of labour. ${ }^{4}$ Both typologies of informalisation are based on industrial regimes that are highly 'unfriendly' towards the labourforce. In India as elsewhere, the garment workforce is a very vulnerable workforce, characterised by precarious working conditions. The 'global' garment industry seems to be systematically unable to generate what the ILO calls 'decent work' (ILO 2004). The recognition and codification of this problem as 'global', as impacting upon all garment producing countries, is at the centre of a rising consensus on the need for global labour standards. That is, global problems need global solutions. However, the next sections will attempt to challenge this view. First, it will focus on the general theoretical contradictions of global labour standards and CSR initiatives in addressing the problems of the working poor. Second, it will discuss their empirical, effective limitations in the Indian case. For this last purpose, the paper will discuss in depth the cases of Delhi and Bangalore. These two Indian garment clusters are experiencing the two different typologies of informalisation briefly mentioned above.

\section{The Globalisation of Labour Standards: Speaking for Capital, Not for the Working poor}

By the 1990s, it became clear that several global industries had disappointing labour 'outcomes'. This was paralleled by the rise of CSR concerns, and the proliferation of what have become known as 'codes of conduct'. These codes, which take the form of factory-based regulations, effectively propose the elaboration and imposition of global labour standards for workers in the 'production nodes' of global commodity chains. Garment production, as one of the key light manufacturing industries largely based on the exploitation of cheap, Southern labour, has been particularly targeted by these codes.

Arguably, ideas over the 'social responsibility' of corporate capital trace back to the $19^{\text {th }}$ century. In the US, the consolidation of the first large corporations was soon followed by the rise of anti-trust regulations and movements. New efforts to regulate corporate activity re-emerged first in the aftermath of the Great Depression, and then by the 1960s, when the main focus of regulation turned towards consumer and environmental protection (Jenkins 2005). By the 1960s and early 1970s, as manufacturing production started being relocated to poorer regions, many developing countries increased efforts to regulate the activities of foreign corporations (Jenkins et al, 2002). At the same time, the regulation of corporate activity became an international effort. In 1974, the UN developed the Draft Code of Conduct on Trans-National Corporations (TNCs). In 
1977, the ILO drafted the Tripartite Declaration of Principles Concerning Multinational Enterprises and Social Policy. It is in this document that the ILO first suggested given standards for labour employed in TNCs. Core labour standards identified were: the abolition of forced labor; the abolition of child labor; the respect for the principle of nondiscrimination at work; and the right to freedom of association (Jenkins et al, 2002).

Unsurprisingly, both national and international efforts towards regulation substantially faded away during the 1980s. The rise and establishment of the neoliberal paradigm and its emphasis on free markets left little room to regulation. In particular, the imposition of any labour standard to developing regions was in open contradiction with policies which praised cheap labour as their main comparative advantage (see Breman 1995). However, by the 1990 s, the social responsibility agenda was resuscitated once again, and started focusing particularly on labour. In fact, during this period, a number of consumers' initiatives started exposing the unfair labour practices deployed by MNCs in poor regions. According to Naomi Klein - who would soon become one of the main anti-brands gurus after writing her 'No-Logo' - the year 1995-1996 in the US could be re-labelled the 'year of the sweatshop'. As campaigning peaked, Kathie Lee Gifford cried on national TV when publicly accused of 'new slavery' (Klein 2000). The business world responded to campaigning, and soon a number of companies started elaborating their own voluntary labour standards; codes of conduct imposing 'fair' labour practices in their factories. This final re-birth of the social responsibility agenda also signalled its profound transformation; it was internalised by corporations. Today, all big global buyers have their own voluntary codes of conduct, broadly inspired by the earlier ILO core standards for labour. Many buyers adhere to multi-stakeholders initiatives, such as the Ethical Trade Initiatives (ETI). ${ }^{5}$ Increasingly, CSR is mainstreamed in the work of international organisations and donors. It is an important component of the new ILO 'decent work agenda' (ILO 2004). ETI itself was created thanks to the pressures of the DFID Responsible Business Unit in 1997-1998 (Jenkins 2005, see also O’Rourke 2006).

Early critics of the CSR agenda underlined what Aristotle would define as its 'impossible probability'. After all, as famously summarised by Milton Friedmann, 'the business of business is business'. This business can hardly be 'self-regulating', as far as labour standards are concerned (Jenkins et al 2002). Others argued that CSR could become 'protectionism with a human face', as the so-called 'social clause' could create strong non-tariff barriers against a number of poor countries unable to comply with a new diktat that effectively imposed new forms of private-led conditionality (see Kabeer 2000). ${ }^{6}$ Moreover, empirical research started showing how codes were often a merely managerial practice, while their impact was very difficult to monitor. ${ }^{7}$ They seem to have variable impacts in different regions and sectors (Jenkins et al 2002) and on different social groups. ${ }^{8}$

More recently, it has been argued that the CSR agenda perfectly mirrors globalisation, as a process whereby the capitalist logic is mainstreamed as the dominant and legitimate one (Blowfield 2005). ${ }^{9}$ Effectively, in the context of CSR, capitalist assumptions become universally valid and are made applicable to realms generally outside that of business practice. In this process, as rightly noted by both Jenkins (2005) and Utting (2009), the relationship between business and society is fundamentally re-crafted. Effectively, the mainstreaming of the CSR agenda can be portrayed as an attempt by 
capital to expand its reach, and escape older forms of control previously imposed by society on business. Moreover, once business is able to define what is 'ethical' or 'unethical', it can not only avoid external control, but it can also create new markets. The proliferation of fair-trade and ethically-responsible consumer goods in western department stores exemplifies this last point. Therefore, the rise of CSR does not simply represent the elaboration of a 'new business model'; rather, it represents the emergence of new organising principles through which business seeks to supersede its traditional social constraints, whilst also expanding its reach to new arenas. It is, in many ways, an active attempt towards the commodification of ethics. It must be noted that this 'moralisation' of markets and the progressive privatisation of regulation are clearly in line with the neoliberal capitalist project (O'Laughlin 2009) and its increasing emphasis on private-led development (Blowfield 2005).

Based on the abovementioned considerations, one could quite easily already conclude that today CSR is a clearly pro-capital agenda, which is not meant to speak for the working poor. Nevertheless, in areas where national labour laws are missing or scarcely implemented, CSR is understandably appealing, and it is hard to simply dismiss it on the basis of theoretical considerations. In some areas and sectors, it is increasingly presented as the only option currently available. Many argue that, even if pro-capital, CSR can also speak for labour. However, it is argued here that this position can be problematic. In fact, as rightly observed by Blowfield (2005), CSR presupposes a universalising economic system, based on a universally legitimised, 'transcendental' form of knowledge. This construct actually clashes against the presence of multiple and varied forms of power and knowledge one can find in the different areas where production is increasingly decentralised. ${ }^{10}$ This point is particularly relevant for the scope of this paper. In fact, the multiple and varied ways in which today the process of informalisation of labour is mediated, produced and reproduced cannot but escape any attempt at imposing global labour standards. The theoretical 'impossible probability' of CSR as an effective agenda for the working poor is empirically confirmed by its limited impact on the ground. In particular, drawing from the experience of the Delhi and Bangalore garment industry, the next sections will show that, on the ground, codes of conducts clash with the 'codes of practice' imposed by local actors and firms.

\section{5. 'Codes of Practice' in Delhi: Migrantisation of Factory Production, Homeworkisation of Value Addition}

In the Delhi garment cluster, the limited impact of CSR practices in the form of labour standards is due to the great fragmentation and parcelisation of the production process and the great variety of mechanisms for labour discipline and control. Here, garment production is a complex world of multiple production spaces. Different agents and actors shape a variety of networks within those spaces, crafting a particular fragmented and layered product cycle. Export firms are at the top of the production hierarchy and of the organisation of the product cycle.

High levels of fragmentation have their roots in Delhi's artisanal heritage in tailoring, which traces back to the Mughal Empire. Shahjanabad, today known as Old Delhi, was already a specialised tailoring centre by 1648, particularly known for 
embroidery. During the Mughal period, skilled artisans operated from household karkhanas (workshops) and catered to royal households. With the decline of the Mughal dynasty, artisans either migrated or created caste or craft-based mahallas (craftsmen shops). With the arrival of the British colonisers, production was organised in market forms of distribution (Blake 1993, Singh and Kaur Sapra 2007). This old artisanal legacy still informs the organisational make-up of the 'modern' export industry. By the 1960s, when export production rose in Okhla (Alam 1992), it was still characterised by small tailoring units organised in putting-out system of production. Until the 1980s, a core of powerful merchants - connected to overseas importers - towered over this army of little artisans without access to final markets (Singh, Kaur and Kaur Sapra 2004; Ambekar Institute of Labour Studies 1980).

Since the 1980s, growth in exports pushed the industry towards new areas; the New Okhla Industrial Development Area (NOIDA) in UP, and Gurgaon and Faridabad in Haryana. Together with Delhi city these areas form the National Capital Region (NCR). ${ }^{11}$ Fieldwork findings reveal that although merchant capital is still very high to date, manufacturing capital is on the rise, and unit size is increasing (see also AEPC data, 2004). On the other hand, however, exporters generally own multiple small or medium firms, rather than single larger factories. AEPC-Delhi reports that there are between 3,000 and 4,000 units in the NCR today, but the number of exporters is much lower. Direct export firms still have limited manufacturing capacity, and rely on high levels of subcontracting. Fieldwork findings also suggest that direct export firms subcontract around 60-70percent of their export orders to a large pool of smaller garment producers, or job-workers, without access to export markets. Therefore, the factory-based realm of production in Delhi is still highly fragmented, and defined by very uneven and hierarchical relations of power between different actors on the basis of their link with final markets. Production techniques inside the units still make substantial use of 'makeand-through' techniques, where one tailor stitches the entire garment. However, groupsystems - where groups of tailors work on one item - and semi-assembly lines are also present. Subcontracting is used to increase manufacturing capacity, but also to perform processing and ancillary activities. Delhi specialises in ladieswear production, where ancillary activities, especially embroidery (as in Mughal times), are very important. After embroidery, the production price of one garment can double (Lal 2004). Embroidery activities take place in a vast, non-factory realm of production, connected to the factory according to the needs of the export firm.

Fieldwork findings show that both factory and non-factory realms of production are inhabited by very casualised and informalised types of labour. However, informalisation in these two realms takes place in qualitatively different ways. The factory-based realm of production makes substantial use of migrant workers from UP and Bihar, among the poorest states of the Hindi belt (Fieldwork interviews; see also Singh and Kaur Sapra 2007). Around 80percent of these workers are casual or temporary labour. Their wages vary very significantly, from firm to firm (direct export firms, for instance, apply higher wage rates than subcontracting firms), and on the basis of workers' skills and experience. Field findings reveal that by 2005 unskilled workers earned just above 2,000 rupees per month, while skilled workers' salaries could range from 3,000 to 10,000 rupees. However, generally only master cutters and master tailors were paid 
between 8,000 and 10,000 rupees. Moreover, wage levels in the industry, as well as systems of payment, also depend on who organise and manage labour networks. ${ }^{12}$ In fact, migrant workers are often organised by local labour contractors, who recruit them in the villages and bring them to Delhi. In Delhi, resident contractors are in charge of dealing with the labour needs of the export firms. The management of the labour process heavily depends upon these agents, who shape patterns of in-contracting. In fact, if a significant share of garment orders is contracted out by garment firms, labour instead is contracted in; a process already described by Portes and Castells (1989) with reference to Latin America. In this fashion, the formalisation of production - linked, for instance, to increases in unit size - can take place without a parallel formalisation of labour relations. Due to their precarious working arrangements, migrant workers aim at maximising their cash inflows during peak season. According to the labour organisations and unions interviewed in the NCR, the average working day in the Delhi garment industry is of at least 14 hours. Migrant workers go back to their villages in UP and Bihar during the lean season, starting in April. According to field findings, this process of circular migration implies a yearly labour turnover in the sector of around 60percent. Exporters argue that these astonishingly high levels of break in service are due to migrant workers' choices. However, these working arrangements benefit tremendously the industry, as they provide a flexible and casualised reservoir of labour. This migrantisation of factory production represents the dominant modality of informalisation in the factory-realm of production in Delhi, and allows for a very efficient minimisation of labour costs.

In the non-factory based realm of production, informalisation processes are particularly complex. Embroidery activities, or embellishment networks (Mezzadri 2008), are orchestrated by specialised agents called thekedaars, and are sub-divided in machine or hand-based activities. Generally, thekedaars specialise in either of these two different activities. Machine-embroidery is carried out on pedal machines; hand-embroidery can either make use of a particular handloom, called the adda, or be simply based on needlework. Machine embroidery takes place in informal units in and around the main industrial areas, in small informal workshops which resembles the old artisanal mahallas Delhi was famous for. Adda-work can either take place in similar informal units, scattered around the main industrial areas, or be entirely decentralised to periurban areas and villages in and around Bareilly, in UP. Here, adda-work, locally mostly known as zari-work, is a traditional skill. Thekedaars mostly need Delhi-based units for sampling purposes, and small or urgent deliveries. However, they decentralise the bulk of embroidery activities to rural household units and homeworkers in UP, in order to benefit from lower labour costs. In Bareilly, adda is an abundant skill. It is practiced by a significant share of local Muslim communities, so it is readily available and less expensive. ${ }^{13}$ Urban-rural wage differentials between Delhi and rural UP are a very effective tool for cost minimisation. Labour costs in the Delhi units, instead, are contained through the substantial use of migratory child labour. Field findings suggest that a large share of these working children come from Bihar. A child labourer is paid half the wage of an adult worker within the piece-rate system adopted by the contractors (Fieldwork interviews and findings, see also Mezzadri 2008). What exporters and contractors call 'simple' needlework, also known as beading or moti-work, takes place in different residential, industrial or commercial areas in Delhi, and it is mostly carried out 
by female homeworkers, who, in this particular production system as in many others in India, are at the bottom of the employment ladder. Overall, in the non-factory realm of production, informalisation manifests itself through different processes of homeworkisation of value-addition. Both in the factory and non-factory based production realms, the process of informalisation reproduces different types of informality, whilst, at the same time, it strongly relies on informal structures and differences- such as gender, age, mobility and/or geographical provenance- to control labour and contain labour costs.

The combination of these different modalities of informalisation is part and parcel of the modus operandi of the export firm in Delhi. It allows cost minimisation and it guarantees the flexibility required by the firms to reproduce their incorporation into global markets, in the specific segment of ladieswear production, which is particularly volatile and characterised by small and fast-changing orders. In this particular setting, global labour standards are deemed to failure. In fact, corporate codes of conduct are elaborated as factory regulations, and assume the presence of a stable and permanent factory labourforce as the a priori condition for their effectiveness. This is hardly the case in Delhi, where factory labour is mainly composed by migrant workers on casual or short-term contracts, and where a significant share of the production process takes place outside the factory realm. Here, codes are not only ineffective, but simply inapplicable. Arguably, they simply replicate the failure of national legislation, whose scarce effectiveness is also due to the large presence of non-permanent labour relations. Recent attempts are currently being made to address this issue. In Bareilly, ETI has recently started a pilot project aimed at improving the conditions of artisans incorporated in the last part of the production process. This project has involved the creation of an organisation gathering a number of local contractors, who are generally seen as the 'evil link' within the chain. ${ }^{14}$ Although at an embryonic stage, this project highlights the presence of great power imbalances in the industry. These imbalances can be measured not simply in terms of capital-labour relations, but also in terms of different 'capitals' and their struggle to survive in the global economy. While contractors are pressurised to change their unfair labour practices, export firms in Delhi refuse to change their use of contractors as a form of disposable capital, and continue to work with them on the basis of kachcha ('raw', informal) contracts and word of mouth. Faced with increasing pressures, contractors continue dumping their rising risks on home-based workers. In this complex scenario, codes cannot possibly regulate labour and improve the lives of the working poor. In fact, this regulation is incompatible with the local architecture of production and the local modalities of informalisation. Labour regulation is instead shaped by specific 'codes of practice' imposed by local actors and firms.

\section{6. 'Codes of Practice' in Bangalore: Feminisation and Re-feminisation of Production}

If the lack of permanent, stable employment relations severely limits the effectiveness of codes of conduct, the presence of such relations does not necessarily guarantee their success. In fact, firms can elaborate strategies and practices in order to 
circumvent labour legislation in ways which effectively even risk re-crafting the very meaning of 'permanent work'. This is the process which seems to take place in Bangalore. The garment industry in Bangalore and Delhi are organised in substantially different ways. Bangalore is characterised by a more compact and centralised production space. It is a 'younger' production centre, and its late entry into garmenting is likely to have impacted both its local industrial trajectory and its product specialisation. Fieldwork findings reveal that the initial growth of garment production was facilitated by the proximity to the fabric producing centres of Salem, in Tamil Nadu, and Kannur (previously Kanannore) in Kerala.

The first garment export economic boom started in the early 1970s, and was led by one family, whom I will call Pakeeza. Arriving in Mumbai from Pakistan after the Partition, the Pakeezas moved to Bangalore where they initially specialised in silk yarn trade. ${ }^{15}$ They moved into garment export in the 1970s. As northern export centres like Delhi had an advantage in mercantile production, the family soon set up its first garment manufacturing unit. By the end of the decade their blossoming export business was divided between the two Pakeeza brothers who founded the two garment colossuses Garment Export and Garment Image. Interviews with key informants and with one family representative (currently running Garment Image) reveal that today the two companies together employ over 30,000 workers, respectively scattered across thirty-six and eighteen units. The Garment Group accounts for a very large share of the whole Bangalore garment export business. The second economic boom started in the second part of the 1990s, and was primarily due to the relocation of garment firms from Mumbai. ${ }^{16}$ Today Bangalore is considered one of the key garment export areas in Southern India, and specialises in basic menswear and outerwear (AEPC 2004, Ambekar Institute of Labour Studies 2005). This type of product is mass produced and requires a more stable and continuous product-cycle than that which characterises Delhi's ladieswear production.

In the 1970s, the Bangalore garment industry was largely concentrated around the Lalbagh area, a crowded commercial neighbourhood. However, soon firms started moving towards the outskirts of the city. Today, production clusters around a few industrial estates; Peenya industrial area, Boomsandra and Mysore Road (RoyChowdhury 2005); as well as Whitefield and Hosur Road (fieldwork interviews). By 2003, there were officially 788 garment manufacturing units in Karnataka, of which 729 were in Bangalore (Sharma 2005). As in Delhi, Bangalore exporters own multiple export units. According to CMAI-Bangalore there are no more than 300 exporters in the city. However, export units are larger than in Delhi, and levels of subcontracting substantially lower. In fact, these units make a more general use of semi-assembly and assembly line production, due to their product specialisation in basic-wear garments. This implies higher entry barriers for subcontractors since direct exporters require that they have at least one batch of assembly line, composing 30-35 machines. In addition, ancillary activities are negligible compared with Delhi; embroidery is generally computerised, and it takes place inside the factories on specialised, capital-intensive machines called 'heads'. Overall, fieldwork findings suggest that factory production dominates the Bangalore garment sector. 
This more compact and even production space, defined by less fragmented product cycles, is inhabited by a very different labourforce compared with what one finds in Delhi. Moving from north to south, the heterogeneous labouring classes which characterise the Indian garment sector makes way for an apparently homogenised labourforce, composed mostly of female factory workers. Trade unions, the Bangalore Labour Commissioner Office and CMAI-Bangalore agree that female labour represents around 90percent of the total factory workforce. At present, next to the beedi industry, the garment industry is considered among the largest employers of women in Karnataka (Roy Chowdhury 2005). According to Sharma (2005), in Bangalore, it is the largest employer in absolute terms. Women workers mainly come from local areas in and around Bangalore, and are generally recruited directly by the firms, through advertisement on notice boards outside the factory, and therefore without the use of labour contractors. Walking around in Peenya industrial area, one can see numerous recruitment notices announcing: 'experienced ladies tailors needed'. Trade unions and labour organisations such as Civic Initiatives for Development (Cividep), which is particularly active in the area and sector in question, confirm that these female workers generally enjoy permanent status. They are paid monthly wages, and employers regularly pay their Provident Fund (PF) and Employee State Insurance (ESI), as accorded by Indian labour legislation. In the Bangalore case, the use of more stable and continuous employment relations is coherent with the industrial requirements of a more standardised and continuous product cycle. At the same time, the use of these employment relations does not clash with - but rather reinforces - the logics of labour cost minimisation in this particular context. Women workers are paid relatively low - albeit stable - factory wages. Also here, wages vary tremendously, particularly from firm to firm and on the basis of experience. Direct export units pay higher wages. Then, in all units, women workers are classified in three different categories; A, B, and C. Category C workers are 'newcomers' in the sector. In 2005, according to Cividep and to the Bangalore Labour Commissioner Office, they were generally offered apprentice wages of around 800 rupees. According to the same informants, Category A workers earned 2,100 rupees per month. Garment Image, instead, claimed to pay 2,100 rupees for unskilled workers and 2,875 for very skilled ones. Either way, factory wages are significantly lower than those paid to male tailors in Delhi. In fact, exporters who own units in both Delhi and Bangalore underline that factory labour costs are much lower in Bangalore. Many explicitly praise Bangalore' docile and cheap 'loving population'.

In a context where factory labour costs are the major share of the overall labour costs, the availability of low factory wages is crucial for export firms. Arguably, low wages are legitimised on the basis of a discourse of de-skilling. Working on assembly and semiassembly lines, women workers are seen as semi-skilled operators rather than skilled tailors, like in Delhi. Gender discrimination reinforces this discourse; these workers are seen as only semi-skilled because of the segmentation of production techniques and because they are women. De-skilling, in this case is constructed in a twofold way; through shop floor organisation and practices, and through gender. Also, women workers are overall perceived as less threatening in terms of potential for unionisation, and therefore they are considered an ideal labourforce to be employed in the larger industrial 
units which characterise the Bangalore garment industry (fieldwork interviews and findings).

The 'permanent status' these women workers supposedly enjoy needs to be questioned. On the one hand, these female workers are directly recruited and provided with permanent contracts; very different from the labourforce engaged in garment production in Delhi. On the other hand, permanent status seems to be progressively subject to a given 'deadline'. Such a deadline, as bitterly put by a trade unionist, is 'four years and eleven months'. In fact, after five years inside the same export firm as a permanent worker, employees are entitled to the payment of a number of bonuses under the Indian labour legislation. The most important of these is gratuity, which is the payment by the employer of fifteen days of work for every year spent in the same firm. Exporters interviewed in Bangalore reported a very high annual labour turnover in their factories. Garment Image factories, for instance, reports an annual labour turnover of 26percent; that is, they effectively change one third of their entire factory workforce every year. This is somehow a striking estimate considering that the industry is formally characterised by a permanent workforce. Firms attribute this trend to voluntary leave, especially on the basis of 'marriage-related' break in service; when workers - whose age group is increasingly young - marry, they either relocate with their husbands, or they stop working altogether. According to unions and labour organisations, workers are forced to leave in order for the firm to avoid payment of gratuity and other bonuses required by Indian labour legislation. Workers are then often encouraged by employers to start working for another unit under a new 'permanent' contract (fieldwork interviews and findings). This particular code of practice adopted by firms in Bangalore mainstreams the logics of informalisation to the permanent factory labourforce - a process Chang (2009) has recently called the 'informalisation of the formal' - effectively challenging the very meaning of permanent work. In this sense, Bangalore's feminised labourforce is subjected to a further wave of feminisation. This labourforce, in fact, experiences a further deterioration of working conditions and a further increase in employment insecurity, even in a context of supposedly secure labour relations. In Bangalore, new and innovative modalities of informalisation, apt at circumventing rather than openly breaching existing labour laws are actually based on these processes of feminisation and re-feminisation of the workforce (see Mezzadri 2009).

Also in this scenario, the potential for codes of conduct to address the needs and problems of the local working poor seems drastically limited. Once again, codes may simply reproduce the failure of national regulation, which is so skilfully circumvented by exporters. The limitations of codes of conduct are more obvious in the case of Delhi; they are elaborated as mere factory regulations, in a context where the factory-realm of production is informally organised and where non-factory production spaces are particularly relevant. However, even in the Bangalore case, the predominance of the factory as the main space where production occurs is not a sufficient condition to guarantee the potential effectiveness of codes. Also in this case, firms engage in practices which have opposing objectives to those formally put forward by the CSR agenda. Firms actively try to avoid the establishment of the very universally legitimised form of knowledge that CSR is supposedly trying to impose. The aim of export firms is still labour fragmentation, lack of cohesiveness and lack of organisation, as they guarantee - 
and in turned are reinforced by - labour cost minimisation. These are fundamental objectives for export firms. They guarantee firms' incorporation into global production networks, by reproducing their comparative advantage in (cheap) labour-intensive production. This advantage, far from being 'natural' as conceived by classic models of international trade, must be actively constructed, produced and reproduced; and firms do so by subjugating labour in a variety of different ways. Through their practices, export firms ensure that, even in their permanent status, Bangalore female workers are still subject to high levels of insecurity. The very logic of feminisation is strongly based on gender discrimination at work; it is crafted to circumvent that right of association which almost all codes of conduct refer to; and the politics of 'PF retention' practiced by employers is not completely inconsistent with that of bondage (indeed, this is the very provoking argument put forward by some unionists). ${ }^{17}$ Once again these practices, which already severely limits the ability of national legislation to protect workers, and which are at the very basis of the local architecture of production and labour control, seem fundamentally inconsistent with attempts to globalise labour standards.

\section{Conclusions: Local Firms, Codes of Practice and the Real Labour Standards}

Today, the question of labour standards is a pressing one. As the globalisation of garment production progresses, its impact on labouring classes seems increasingly harsh. Production nodes of global commodity chains and production networks are characterised by different sweatshop systems, where labour is increasingly casualised and informalised in multiple different ways. Informalisation involves a systematic exploitation of informal mechanisms to control the labourforce, based on deeply-rooted inequalities and structural differences, such as gender, age, geographical provenance and rural-urban wage differentials. India is experiencing a process of de-facto informalisation pictured by aggregate data (Rani and Unni 2004). Here, fieldwork findings reveal that informalisation manifests itself with different modalities, producing and reproducing very different labouring classes who share very insecure and vulnerable working conditions. The general race to the bottom experienced by garment workers in different regional settings has been progressively conceptualised as a global concern that needs global solutions. Since the mid 1990s, CSR initiatives and in particular codes of conduct for labour have been put forward as one possible global solution. However, these initiatives, seem to be clearly pro-capital, as they are increasingly mainstreaming business values to the realm of 'the social', altering the original balance between business and society in favour of the former (Jenkins 2005, Blowfield 2005). CSR is pushing business well outside its traditional boundaries; at the same time it is also providing it with new market possibilities.

Despite its theoretical flaws, CSR is difficult to dismiss. In many regions, where labour laws are missing or poorly implemented, the corporate world starts being seen as the regulator of last resort. Corporate labour standards - as the argument goes - are better than no standards. However, even this point is problematic. In fact, a key question to address is: who really sets labour standards in practice, why and how? This paper has shown that these standards are crucially influenced by firms' codes of practice. These help 
pave the way for given patterns of informalisation, sustaining firms' comparative advantage in cheap labour, and reproducing their incorporation into the global economy. Standards are crucially shaped by these codes of practice, which are elaborated by firms to guarantee labour control and labour cost minimisation. The attempt at globalising labour standards through the imposition of general corporate codes of conduct clashes against these codes of practice, as the latter are instead deeply embedded in the local economy, in local forms of knowledge and power. In fact, these codes of practice do not aim at a universal codification of the labour relation. On the contrary, they aim at splintering and disorganising, making 'the labour experience' as atomised as possible.

The two cases discussed in this paper highlight the different ways in which the codes of practice imposed by local firms, which already clash with Indian labour legislation, effectively also clash with corporate codes of conduct. In Delhi, these codes of practice trigger patterns of informalisation based on the migrantisation of factory work and different types of homeworkisation of value addition. Here, the limited applicability of codes is due to their prime elaboration as factory regulations, in a context where, instead, very fragmented and informalised industrial and labour regimes dominate, and where a substantial part of the production process takes place in non-factory settings. Despite the dominance of the factory realm of production and apparently permanent labour relations, the applicability of codes of conduct also needs to be questioned in the case of Bangalore. Here, firms engage in practices which are apt to circumvent labour laws- without necessarily breaching them- and which are effectively changing the very meaning of permanent work. Bangalore, characterised by a feminised labourforce, is today experiencing new, 'innovative' modalities of informalisation based on new waves of feminisation and re-feminisation of the workforce. Firms' strategies actively empty the 'permanent status' of workers of real meanings in socio-economic terms, exposing also permanent workers to increasing levels of insecurity.

The theoretical and empirical analysis discussed here allows for some concluding methodological reflections, which can be relevant for the study of labour standards in the future. In fact, the recognition of the relevance of firms' codes of practices in crafting and reproducing such standards has clear methodological implications. The firm, in this case, becomes a fundamental analytical prism through which the study of labour conditions can actually be enhanced. It is not simply the physical space where one can analyse labour trends, dynamics and shop floor organisation; it is a highly charged political space where one can observe capital's daily struggle to subjugate and domesticate labour and reproduce its commodification in multiple ways. This struggle has a crucial impact on patterns of labour deployment, exploitation and on patterns of labour control. Working conditions - the real labour standards - are an outcome of this struggle. By looking at labour through capital, very useful lessons can be learnt on how specific working conditions are imposed, reproduced, and why. This can be an important exercise in order to find new ways to improve those conditions, and to move towards an agenda that could finally speak for the working poor.

These are methodological reflections; however, they also have clear political implications. While we need the elaboration of new, meaningful labour rights agendas, these agendas should start from an understanding of how capital works in given geographical settings, not simply focusing on technicistic, one-size-fits-all approaches to 
working conditions. In this sense, the author still sees national legislation as the key, crucial sphere of competence in terms of labour standards, particularly in a country like India, which hosts a huge share of the world's working poor. Potential failures in the implementation of national labour norms (like in the two cases discussed here) do not necessarily imply the need for supranational forms of legislation, as the latter may simply replicate such failures (like in the two cases discussed here). Rather, they indicate the need for a re-tuning of such national norms, in the light of contemporary processes of capital reorganisation. The extent to which supranational legislation can at least provide useful platforms for national labour struggles is a compelling question, and one which deserves both research and political attention in the future. However, so far, this type of legislation has too often led to projects which can be very easily highjacked by capital.

\section{NOTES}

1. Qualitative material is based on interviews held with exporters, contractors, unions, business and labour organisation and, occasionally, focus groups with workers. The fieldwork aimed at exploring production and labour regimes in the eight main export centres in India, their different incorporation into global production networks, and the different modalities of local processes of informalisation. This paper focuses only on two centres - Delhi and Bangalore. The 2004-2005 fieldwork round was highly mobile, as I travelled numerous times across the different garment centres. Disaggregating 'field time' spent in each centre is therefore not an easy task. My understanding of the industry benefited greatly from constant comparisons across centres, made possible via this process of relentless travelling. This is particularly true for the Delhi case. While I have engaged in in-depth fieldwork in and around Delhi between October and November 2004 and between May and July 2005, my understanding of the industry was also greatly enhanced by shorter fieldwork spells carried out throughout the year. Between April and May 2010, a new round of fieldwork was carried out in Bareilly, in Western Uttar Pradesh, a core site for embellishment networks. Fieldwork in Bangalore was mainly carried out between December 2004 and January 2005. A second short trip was also arranged, in May 2005. For a full analysis of the Indian garment industry, see Mezzadri (2009).

2. This is the case for Delhi, Jaipur, Chennai, Bangalore and Mumbai, while for Tiruppur TEA suggests these estimates account for both factory and non-factory based labour (TEA, interviews).

3. See also Unni and Rani (2008).

4. For a detailed picture of local processes of informalisation in the industry, see Mezzadri (2009).

5. For a discussion of other multi-stakeholders initiatives, see Sum and Pun (2005). 
6. On a similar vein, but focusing on buyers-suppliers relations, De Neve (2009:71) more recently defined ethical standards as 'new yardsticks of modernity'.

7. Looking at the case of two factories in China, Pun (2005) underlines how in many instances training sessions on social compliance target middle and upper managerial staff (such as supervisors or line-leaders) rather than workers. Seidman (2009) highlights the general limitations of voluntary monitoring systems in South Africa, India and Guatemala.

8. Looking at the African export horticulture sector, Barrientos, Dolan and Tallontire (2003) discuss the limited impact of codes on women. Prieto-Carron et al (2006) highlight the relevance to explore how power, class and gender mediate CSR interventions.

9. This proliferation of codes of conduct during the global era has been defined by Sum and Pun (2005: 198) as 'neo-liberal globalisation with an audit'.

10. For instance, in his study of child labour in Sialkot, Nadvi (2008) refers to the disjuncture between CSR discourse and local discourses on apprenticeship systems.

11. The industry is further spreading towards greater NOIDA (further down in UP) and along the Delhi-Jaipur highway.

12. Tailors can be paid piece rate, daily or weekly wages, based on different production techniques and arrangements with contractors. Singh and Kaur Sapra (2007) show that contractors retain a percentage of workers' wages - generally between 15 and 30percent. Due to all these variables, it is hard to calculate average wages in the sector.

13. Unni and Scaria (2009) analyse the different local Muslim communities engaged in this activity, highlighting capital-labour distinctions. According to their study, upper caste Muslims such as Khans are highly represented among contractors, while lower castes such as Ansaris are overrepresented among workers.

14. See for instance, the Panorama documentary 'Primark on the Rack', screened by the BBC in 2008.

15. Bangalore is also close to two silk clusters: Kancheepuram, in Tamil Nadu, and Ramanagaram, in Karnataka (Benjamin, 2000).

16. In Mumbai, many garment units started closing down in the early 1980s (Krishnaraj 1987), due to increases in real estate prices (see D’Monte, 2002), land shortage, and the impact of the famous labour strikes in the mills sector (see Chandavarkar, 1992). 
17. It is reported that employers retain PF until workers accept to 'voluntary' terminate their former permanent contract and start a new one. According to some unionists, this praxis effectively bond workers. While this is a provoking statement, indeed many workers in the Indian garment sector experience different degrees of 'unfreedom'. In fact, drawing from Jairus Banaji's (2003) work, I have already shown elsewhere (see Mezzadri 2008) how the Delhi garment industry incorporates and exploits different forms of 'unfree' labour.

\section{REFERENCES}

AEPC (2004) Handbook of Export Statistics, data from 1983-2003, various issues. New Delhi: Apparel Export Promotion Council.

Alam, G. (1992) 'Industrial Districts and Technological Change: A Study of the Garment Industry in Delhi', Mimeo. New Delhi: Centre for Technological Studies.

Ambekar Institute of Labour Studies (1980) Problems of Clothing Industry in India - A Trade Union View, report presented at the International Labour Organisation second tripartite technical meeting for clothing industry, Geneva, 23 September2 October 1980, Mumbai: Ambekar Institute of Labour Studies.

Ambekar Institute of Labour Studies (2005) Textile and Clothing Industries in India and Phasing out of MFA - A Study Report, internal report. Mumbai: Ambekar Institute of Labour Studies.

Banaji, J. (2003) 'The Fictions of Free Labour: Contract, Coercion, and So-called Unfree Labour', Historical Materialism 11(3):69-95.

Bair, J. (2005) 'Global Capitalism and Commodity Chains: Looking Backward, Going Forward', Competition and Change 9(2): 163-180.

Barrientos, S., Dolan, C. and Tallontire, A. (2003) 'A Gendered Value Chain Approach to Codes of Conduct In African Horticulture', World Development 31(9): 15111526.

Benjamin, S. (2000) 'Governance, Economic Settings and Poverty in Bangalore', Environment and Urbanization 12(1): 35-56.

Blake, S. (1993) Shahjahanabad: The Sovereign City in Mughal India 1639-1739, Cambridge South Asian Studies Series. Cambridge: Cambridge University Press. 
Blowfield, M. (2005) 'Corporate Social Responsibility: Reinventing the Meaning of Development?', International Affairs 81(3): 515-524.

Bonacich, E. and Appelbaum, R. (2000) Behind the Label. Berkeley, California: University of California Press.

Bonacich, E., Cheng, L., Chinchilla, N., Hamilton, N. and Ong, P. (1994) Global Production: the Apparel Industry in the Pacific Rim. Philadelphia: Temple University Press.

Breman, J. (1995) 'Labour, Get Lost: A Late Capitalist Manifesto,' Economic and Political Weekly, September 16.

Castells, M. and Portes, A. (1989) 'World Underneath: the Origins, Dynamics and Effects of the Informal Economy', in A. Portes M. Castells and L.A. Benton, The Informal Economy: Studies in Advanced and Less Developed Countries (pp. 11-37). Baltimore: John Hopkins University Press.

Chan, A. (2000) 'Globalization, China's Free (Read Bonded) Labour Market, and the Chinese Trade Unions', Asia Pacific Business Review 6(3): 260-281.

Chandavarkar, R. (1992) The Origins of Industrial Capitalism in India: Business Strategies and the Working Classes in Bombay, 1900-1940. Cambridge: Cambridge University Press.

Chang, D. (2009) 'Informalising labour in Asia's Global Factory', Journal of Contemporary Asia 39(2): 161-179.

D’Monte, D. (2002) Ripping the Fabric: The Decline of Mumbai and Its Mills. New Delhi: Oxford University Press.

De Neve, G. (2009) 'Power, Inequality and Corporate Social Responsibility: The Politics of Ethical Compliance in the South Indian Garment Industry', Economic and Political Weekly 44(22): 63-72.

Gereffi, G. and Korzeniewicz, M. (1994) Commodity Chains and Global Capitalism. Westport, Connecticut: Praeger Publishers.

Harriss-White, B. (2003) India Working: Essays on Society and Economics. Cambridge: Cambridge University Press.

Howard, A. (1997) 'Labor, History, and Sweatshops in the New Global Economy', in A. Ross (ed) No Sweat: Fashion, Free Trade and the Rights of Garment Workers (pp. 151-172). London: Verso. 
ILO (2004a) A Fair Globalisation: Creating Opportunities for All, ILO World Commission on the Social Dimension of Globalization. Geneva: ILO.

ILO (2004b) Economic Security for a Better World, ILO Socio-Economic Security Programme. Geneva: ILO.

Jenkins, R. (2005) 'Globalization, Corporate Social Responsibility and Poverty', International Affairs 81(3): 525-540.

Jenkins, R., Pearson, R. and Seyfang, G. (2002) Corporate Responsibility and Labor Rights - Codes of Conduct in the Global Economy. London: Earthscan Publications.

Kabeer, N. (2000) The Power to Choose: Bangladeshi Women and Labor Market Decisions in London and Dhaka. London: Verso.

Klein, N. (2000) No Logo: No Space, No Choice, No Jobs: Taking Aim at the Brand Bullies. London: Flamingo.

Krishnaraj, M. (1987) 'New Opportunities and Old Terms, the Case of the Garment Industry in India', pamphlet. Mumbai: Research Centre for Women's Studies, SNDT Women's University.

Lal, T. (2004) 'Diagnostic Study, Report and Action Plan for the Ready Made Garment Cluster'. New Delhi: Government of India, SISI Okhla, Cluster Development Executive Section.

Mezzadri, A. (2008) 'The Rise of Neoliberal Globalisation and the "New Old" Social Regulation of Labour: The Case of Delhi Garment Sector', Indian Journal of Labour Economics 51(4): 603-618.

Mezzadri, A. (2009) 'The Architecture of Production and Labour Control in the Indian Garment Industry: Informalisation and Upgrading in the Global Economy', unpublished $\mathrm{PhD}$ thesis submitted to the University of London, SOAS.

Nadvi, K. (2008) 'Global Standards, Global Governance and the Organization of Global Value Chains', Journal of Economic Geography 8: 323-343.

Ngai-Ling, S. and Pun, N. (2005) 'Paradoxes of Ethical Transnational Production: Codes of Conduct in a Chinese workplace', Competition and Change 9(2): 181200 .

O'Laughlin, B. (2009) 'Governing Capital? Corporate Social Responsibility and the Limits of Regulation', Development and Change 39(6): 945-957.

O’Rourke, D. (2006) 'Multi-stakeholder Regulation: Privatising or Socialising Global 
Labour Standards?', World Development 34(5): 899-918.

Panorama (2008) Primark on the Rack, documentary screened on BBC, 3 June 2008.

Prieto-Carron, M. et al (2006) 'Critical Perspectives on CSR and Development: What we Know, What we Don't Know and What we Need to Know', International Affairs 82(5):967-987.

Pun, N. (2005) Made in China: Women Workers in a Global Workplace. London: Duke University Press.

Pun, N. (2005) 'Global Production, Company Codes of Conduct, and Labor Conditions in China: A Case Study of Two Factories', China Journal 54: 101-113.

Ramaswamy, K.V. and Gereffi, G. (2000) 'India's Apparel Exports: the Challenge of Global Markets', Developing Economies 28(2): 186-210.

Rani, U. and Unni, J. (2004) 'Unorganised and Organised Manufacturing in India, Potential for Employment Generating Growth', Economic and Political Weekly 39(41): 4569-4580.

Rosen, E. (2002) 'Making Sweatshops: The Globalisation of the US Apparel Industry'. Berkeley: University of California Press.

Roy Chowdhury, S. (2005) 'Labor Activism and Women in the Unorganized Sector, Garment Export Industry in Bangalore', Economic and Political Weekly 40(2223): $2250-2255$.

Salzinger, L. (2003) Gender in Production. Berkley: University of California Press.

Seidman, G. (2009) 'Transnational Labour Campaigns: Can the Logic of the Market be Turned Against Itself?', Development and Change 39(6):991-1003.

Sharma, M. (2005) 'Globalisation with a Female Face: Issues from South Asia', in S. Kak and B. Pati (eds.) Exploring Gender Relations: Colonial and Post Colonial India (pp. 463-490). New Delhi: Nehru Memorial Museum and Library.

Singh, N. and Kaur Sapra, M. (2007) 'Liberalisation in Trade and Finance: India's Garment Sector', in B. Harriss-White and A. Sinha (eds.) Trade Liberalisation and India's Informal Economy (pp. 42-127). New Delhi: Oxford University Press.

Singh, N., Kaur, R. and Kaur Sapra, M. (2004) Continents Wide Layers Deep: The Ready Made Garment Industry in the Times of Restructuring, draft copy provided by author (Singh). New Delhi: National Council of Applied Economic Research. 
Standing, G. (1999) 'Global Feminization Through Flexible Labor: A Theme Revisited' in World Development, 27(3): 583-602.

Tewari, M. (2008) 'Varieties of Global Integration: Navigating Institutional Legacies and Global Networks in India's Garment Industry', Competition and Change 12(1):49-67.

UNIDO (2009) The Impact of World Recession on the Textile and Garment Industries in Asia, Working Paper 17/2009. Vienna: UNIDO.

Unni, J. and Scaria, S. (2009) 'Governance Structure and Labour Market Outcomes in Garment Embellishment Chains', Indian Journal of Labour Economics 52(4):631650 .

Unni J. and Rani U. (2008) Flexibility of Labour in Globalising India, the Challenge of Skills and Technology. New Delhi: Tulika Books

Utting P. (2009) 'The struggle for Corporate Accountability', Development and Change 39(6):959-975.

\section{BIOGRAPHICAL NOTE}

ALESSANDRA MEZZADRI is a lecturer in Development Studies at SOAS, London. Contact email: am99@soas.ac.uk. The author wishes to thank Geert De Neve, Marina Prieto-Carron, Sally Smith, Khalid Nadvi, Kate Meagher, Paolo Novak, Susan Newman, the editors of this special issue - Isabelle Guerin, Ravi Srivastava and Jens Lerche - and two anonymous reviewers for their constructive comments on earlier versions of this paper. 